\title{
Cost Analysis of Processing of Green Fodder Crops in Punjab State
}

\author{
Harparteet Singh, Varinder Pal Singh* and Inderpreet Kaur
}

\author{
Department of Dairy Economics and Business Management, College of Dairy Science and \\ Technology, Guru Angad Dev Veterinary and Animal Sciences University, \\ Ludhiana-140111, Punjab, India \\ *Corresponding author
}

\section{A B S T R A C T}

\begin{tabular}{|l|}
\hline Ke y w o r d s \\
Fixed cost, Garrett's \\
ranking, Total cost, \\
Silage, Variable cost
\end{tabular}

\section{Key words}

Silage, Variable cost

\section{Introduction}

Livestock have been an integral component of India's agricultural and rural economy since time immemorial. Livestock is an important asset for them which provide employment to millions of rural people. Most often livestock is the only source of cash income for subsistence farmers as well as ensuring family purchasing power in the event of crop failure.

Presently, livestock sector contributes 25.70 per cent of agricultural GDP in India (Anonymous 2017a) and 36.01 per cent in Punjab state (Anonymous 2017b). Despite being the leading milk producer nation, the
Indian dairy sector is plagued by several hurdles such as low productivity of animals, inadequate availability of quality green fodder and quality fodder seeds etc. The country is highly deficient in respect of availability of green fodder, dry fodder and concentrates. The deficit of green fodder currently is 35 percent (Anonymous 2012).

Any attempt towards enhancing green fodder availability would result in increased margin of profits to livestock owners. Standing at 40 per cent even today, the availability of good quality upgraded fodder seeds and conservation of fodder either as silage or hay remains a major concern (Narke, 2017). 
For enhancing overall productivity of the dairy sector, a steady and adequate supply of quality fodder is required for supporting the livestock population. The feed given to milch animals comprises of green fodder, dry fodder and concentrates. Productivity can be increased by realizing the genetic potential of the animals through ration balancing. The genetic potential of the animals for milk production cannot be realized until they are properly fed. Under feeding is a major hurdle in vertical growth of this sector. When a milch animal is fed a balanced diet, it receives the required nutrients to produce milk commensurate with its genetic potential. Therefore, addressing the issue of feed and fodder management deserves utmost importance. Among the livestock products, milk is the most important. The economic viability of milk production heavily depends on source (s) of feed and fodder as feeding cost account for about 70-75 percent of the total variable cost of dairy farming. Profitable livestock farming depends mainly on adequate availability of fodder with reasonable price.

Green fodder is the essential component of feeding milch animals to obtain optimum level of milk production which account for about 44 per cent of the feed and fodder expenditure (Kaur et al., 2012). Hence, any effort towards enhancing green fodder productivity and production will go a long way in improving the green fodder availability and will be helpful in bringing down the cost of feeding and thereby leading to higher profitability.

When it comes to enhancing the productivity of Punjab's dairy sector, ensuring an adequate supply of reasonable quality feed and fodder is one of the major challenges. The green fodder deficiency in Punjab state was estimated to be 22.99 million tonnes which was 28.57 per cent of the total green fodder requirement (Singh et al., 2018). Owing to problem of shortage of fodder and feed, the future growth of livestock has to be sustained primarily on enhancement of animal productivity and not on increase in number of animals. Efforts need to be made for reducing the gaps between requirement and availability of green fodder by technological interventions to increase the fodder yields and preservation of fodder. The study will provide useful information to future researchers and stakeholders in the dairy sector. In the backdrop of this, the present study was undertaken with the following objectives:

To estimate costs involved in processing (silage making) from various fodder crops in Punjab state.

To study reasons for processing of important green fodder crops in Punjab.

\section{Materials and Methods}

The study was conducted in three agroclimatic zones of Punjab state viz. Sub Mountainous zone (comprising of Sahibzada Ajit Singh Nagar, Rupnagar, Shaheed Bhagat Singh Nagar, Hoshiarpur and Pathankot districts with a total geographical area of 820 thousand ha (16.29 per cent), Central zone (comprising of Amritsar, Gurdaspur, Tarn Taran, Jalandhar, Kapurthala, Ludhiana, Barnala, Moga, Sangrur, Patiala and Fatehgarh Sahib districts with a total geographical area of 2725 thousand ha (54.14 per cent) and South Western zone (comprising of Bathinda, Sri Muktsar Sahib, Mansa, Faridkot, Firozpur and Fazilka districts with a total geographical area of 1488 thousand ha (29.57 per cent). Three districts, one from each zone, was selected purposively on the basis of the highest area under fodder crops. Amongst the selected districts, two blocks from each district, one block near and one distant to the periphery of district headquarter was selected. A sample of 20 fodder growing farmers from each cluster was selected making a total sample of 120 farmers. 
Out of sample of 120 fodder growers, only two farmers, one from south western zone and one from central zone, were involved in fodder processing i.e. silage making. To study the cost structure of fodder processing in detail, a sample of 16 persons associated with the processing of green fodder was randomly chosen from the selected blocks to know the different stages of the fodder processing and to assess the costs involved at each stage. Primary data was collected using a specially designed and pre-tested schedule by personal interview method for the agricultural year 2016-17.

In order to accomplish the objectives of the study, appropriate statistical tools and techniques like averages and percentages etc. were used to draw relevant inferences. Garrett's Ranking Technique has been used to analyze the reasons for by fodder growers in different zones. Under the Garrett's Ranking Technique, the percentage position is calculated by using the following formula:

Percentage Position $=\frac{100\left(\mathrm{R}_{\mathrm{ij}}-0.5\right)}{\mathrm{Nj}}$

Where;

$\mathrm{R}_{\mathrm{ij}}=$ Rank given for $\mathrm{i}^{\text {th }}$ variable by the $\mathrm{j}^{\text {th }}$ respondent.

$\mathrm{N}_{\mathrm{j}}=$ Number of variables ranked by the $\mathrm{j}^{\text {th }}$ respondent.

\section{Results and Discussion}

\section{Cost of processing of green fodder crops}

Out of the 120 sample size of fodder growers, only two were involved in processing of green fodder. A sample of sixteen more processors was selected randomly from the selected blocks for studying the processing of green fodder in detail. Initial capital investment required was observed to be Rs. 1,49,828 out of which Rs. 1,31,924 was on harvesting machinery and Rs. 17,904 on making silage pits. Cost involved in silage making from various fodder crops of Punjab state is presented in table 1. A perusal of the table revealed that the farmers involved in the processing of green fodder were practicing silage making for three crops namely maize, bajra and sorghum. A scrutiny of table brought out that for maize, bajra and sorghum crops, total fixed cost which includes depreciation of harvesting machinery, interest and rent of machinery was Rs. 11.29/q, 11.31/q and $16.27 / q$, respectively. The variable cost for maize crop which includes loading/unloading, transportation, chaffing, etc. was the highest i.e. Rs. $20.20 / \mathrm{q}$ out of which harvesting cost was maximum i.e. Rs. 4.91/q followed by the transportation cost Rs. 4.79/q and plastic sheet used Rs. 3.45/q. Similarly, the variable cost of silage making was Rs. 18.77/q and Rs. 14.70/ $\mathrm{q}$ for bajra and sorghum crops. The total cost of silage making was the highest in maize crop with Rs. 31.50/q followed by the sorghum (Rs. 30.98/q) and bajra (Rs. 30.07/q). The processing of fodder in the form of silage saves the labour cost and helps in reducing the variable cost of milk production by about 8-10 per cent.

Further, regarding the other parameters of silage making, the amount stored in pit varied between 1300 and 2100 quintals, period of storage from 6 to 10 months and period required for preparation of silage from 43-47 days for different crops. About 76.92 percent of maize was home grown and 23.08 percent of it was being purchased from outside. Similarly, for bajra, 88.90 percent was home grown fodder and rest 11.11 percent was purchased from outside. For sorghum crop, there was no purchase from outside as whole crop was home grown. There was approximately 3-4 percent loss in preparation 
of silage. Elumalai 2012 reported that the processing of fodders was also not so prevalent among the farmers. None of the respondent of the study area found to be involved in the processing (Hay and Silage making) and marketing of fodder in M.P (Sharma and Raghuwanshi, 2010).

\section{Reasons for processing}

The reasons for processing given by the fodder growers are discussed in detail in this section. A total of five reasons for processing have been reported in the state. The fodder growers were asked to rank these five reasons as 1, 2, 3, 4 and 5. The calculated percentage positions for various ranks and their corresponding Garrett's table values are given in Table 2. For rank 1, the calculated percentage position was 10 and the table value was 75 . This value is given in the Garrett's ranking table for the percentage 10.06, which is very close to 10 . Similarly, the Garrett's table values were noted for other ranks from the Garrett's ranking table.

The number and percentage of responses given by different fodder growers for various reasons for processing is presented in Table 3.

The table showed that maximum number of the farmers (94.44 percent) reported the reason of ensuring access to fodder at uniform prices followed by preserved fodder is more liked by animals (72.22 percent), ensure regular supply of fodder (66.67 percent) and preserved fodder is more nutritious $(50.00$ percent).

Table.1 Cost involved in Silage making from various fodder crops in Punjab state

\begin{tabular}{|c|c|c|c|c|}
\hline \multirow{2}{*}{ Sr. No. } & \multirow[t]{2}{*}{ Particulars } & \multicolumn{3}{|c|}{ Crops } \\
\hline & & Maize & Bajra & Sorghum \\
\hline A & Fixed cost & & & \\
\hline i. & Depreciation & 4.20 & 4.09 & 6.85 \\
\hline ii. & Interest & 5.76 & 6.55 & 9.42 \\
\hline iii. & Rent & 1.33 & 0.67 & - \\
\hline iv. & Sub total & 11.29 & 11.31 & 16.27 \\
\hline B & Variable cost & & & \\
\hline i. & Harvesting & 4.91 & 4.68 & 2.93 \\
\hline ii. & Loading/unloading & 2.85 & 3.13 & 3.07 \\
\hline iii. & Transportation & 4.79 & 4.47 & 5.42 \\
\hline iv. & Chaffing & 2.13 & 2.03 & 1.64 \\
\hline v. & Chemical used & 2.08 & 1.34 & - \\
\hline vi. & Plastic Sheet & 3.45 & 3.12 & 1.64 \\
\hline vii. & Sub total & 20.21 & 18.77 & 14.70 \\
\hline viii. & Total cost of processing & 31.50 & 30.08 & 30.97 \\
\hline C & Other parameters of silage making & & & \\
\hline i. & Average amount stored (q) & 2068.84 & 1563.33 & 1295 \\
\hline ii. & Period of storage (months) & 8.08 & 6.44 & 9.50 \\
\hline iii. & Period required for preparation (days) & 43.62 & 47.22 & 45.00 \\
\hline iv. & Home grown fodder $(\%)$ & 76.92 & 88.90 & 100.00 \\
\hline v. & Purchased fodder (\%) & 23.08 & 11.10 & - \\
\hline vi. & Percent of silage prepared & 96.82 & 96.89 & 97.65 \\
\hline
\end{tabular}


Table.2 Percentage positions and their corresponding Garrett's table values

\begin{tabular}{|c|c|c|}
\hline Rank & Percentage position & Garrett's Table value \\
\hline $\mathbf{1}$ & 10.00 & 75 \\
\hline $\mathbf{2}$ & 30.00 & 60 \\
\hline $\mathbf{3}$ & 50.00 & 50 \\
\hline $\mathbf{4}$ & 70.00 & 40 \\
\hline $\mathbf{5}$ & 90.00 & 25 \\
\hline
\end{tabular}

Table.3 Number and percentage of responses for reasons for processing

\begin{tabular}{|c|l|c|c|}
\hline S. No. & \multicolumn{1}{|c|}{ Factors } & $\begin{array}{c}\text { No. of farmers } \\
\text { (Total = 18) }\end{array}$ & $\begin{array}{c}\text { Percentage of } \\
\text { responses }\end{array}$ \\
\hline $\mathbf{1}$ & Ensure access to fodder at uniform prices & 17 & 94.44 \\
\hline $\mathbf{2}$ & Preserved fodder is more liked by animals & 13 & 72.22 \\
\hline $\mathbf{3}$ & Preserved fodder is more nutritious & 9 & 50.00 \\
\hline $\mathbf{4}$ & Ensure regular supply of fodder & 12 & 66.67 \\
\hline $\mathbf{5}$ & Shortage of land for fodder production & 2 & 11.11 \\
\hline
\end{tabular}

Table.4 Ranking of reasons for processing being given by fodder growers in Punjab

\begin{tabular}{|c|c|c|c|c|c|c|c|c|c|c|}
\hline \multirow{2}{*}{$\begin{array}{l}\text { S. } \\
\text { No. }\end{array}$} & \multirow[t]{2}{*}{ Reasons } & \multicolumn{5}{|c|}{ Rank } & \multirow{2}{*}{$\begin{array}{l}\text { Total no of } \\
\text { respondents }\end{array}$} & \multirow{2}{*}{$\begin{array}{l}\text { Total } \\
\text { Score }\end{array}$} & \multirow{2}{*}{$\begin{array}{l}\text { Mean } \\
\text { Score }\end{array}$} & \multirow[t]{2}{*}{ Rank } \\
\hline & & 1 & 2 & 3 & 4 & 5 & & & & \\
\hline 1 & $\begin{array}{l}\text { Ensure access to fodder } \\
\text { at uniform prices }\end{array}$ & 4 & 5 & 6 & 2 & 0 & 17 & 980 & 57.65 & II \\
\hline 2 & $\begin{array}{l}\text { Preserved fodder is more } \\
\text { liked by animals }\end{array}$ & 5 & 3 & 1 & 2 & 2 & 13 & 735 & 56.54 & III \\
\hline 3 & $\begin{array}{l}\text { Preserved fodder is more } \\
\text { nutritious }\end{array}$ & 0 & 2 & 1 & 4 & 2 & 9 & 380 & 42.22 & IV \\
\hline 4 & $\begin{array}{l}\text { Ensure regular supply of } \\
\text { fodder }\end{array}$ & 5 & 2 & 4 & 1 & 0 & 12 & 735 & 61.25 & I \\
\hline 5 & $\begin{array}{l}\text { Shortage of land for } \\
\text { fodder production }\end{array}$ & 0 & 0 & 0 & 1 & 1 & 2 & 65 & 32.50 & V \\
\hline
\end{tabular}

The number of farmers giving various ranks to various reasons for processing, total score, mean score and ranks assigned to various reasons is presented in Table 4. For the reason of ensure access to fodder at uniform prices, the total score i.e. 980 was calculated by multiplying the number of famers ranking this reason as 1,2,3,4 and 5 with their respective Garrett's table values and taking the sum. Mean score for this problem i.e. 57.65 was calculated by dividing the total score by respective number of farmers. Similarly, the total score and mean score was calculated for other problems. The reason with the highest mean score was given first rank and the reason with next the highest mean score was given second rank and so on. According to the Garrett's ranking, among the reasons for processing given by fodder growers, ensuring regular supply of fodder got the first rank followed by ensure access to fodder at uniform prices, preserved fodder is more liked by animals, preserved fodder is more nutritious and shortage of land for fodder production. 


\section{Acknowledgements}

The paper has been culled from the M.Sc. Dairy Economics thesis of the first author completed under the guidance of second and third author as major advisor and advisory committee member, respectively and submitted to GADVASU, Ludhiana as partial fulfillment of degree requirements during 2017. The authors are grateful to Dr A.S. Nanda, Vice Chancellor, Guru Angad Dev Veterinary and Animal Sciences University, Ludhiana for providing necessary infrastructural facilities for carrying out the research. The authors are also thankful to the respondents for their kind support in providing the requisite data for the study.

From the foregoing discussion, it has been observed that the farmers involved in the processing of green fodder were practicing silage making for three crops namely maize, bajra and sorghum. The total cost of silage making was the highest in maize crop with Rs 31.50/q followed by the sorghum (Rs 30.98/q) and bajra (Rs 30.07/q). According to the Garrett's ranking, among the reasons for processing given by fodder growers, ensuring regular supply of fodder got the first rank followed by ensure access to fodder at uniform prices, preserved fodder is more liked by animals, preserved fodder is more nutritious and shortage of land for fodder production. As only two farmers out of sample of 120 farmers were engaged in processing of green fodder in the form of silage making, there is need of popularizing the silage making by farmers to ensure regular supply of fodder at uniform prices and enhancing production and profitability from dairy farming. The processing of fodder in the form of silage saves the labour cost and helps in reducing the variable cost of milk production by about $8-10$ per cent. The farmers should be made aware about the incentives available in the form of subsidies for covering the initial cost of silage pit making by government for adoption of silage making.

\section{References}

Anonymous. 2012. 'Report of the working group on animal husbandry and dairying for fiveyear plan (2012-2017)' Planning Commission, Govt. of India, New Delhi.

Anonymous. 2017a. Basic Animal Husbandry Statistics 2016. Department of Animal Husbandry, Dairying and Fisheries, Ministry of Agriculture, Government of India, New Delhi.

Anonymous. 2017b. Statistical Abstract of Punjab 2016. Economic Advisor to Government, Economic and Statistical Organization, Chandigarh.

Elumalai, K. 2012. Economics of Production, Processing and Marketing of Fodder crops in Karnataka' Research Report. Agricultural Development and Rural Transformation Centre. Institute for Social and Economic Change, Bangalore.

Kaur, I., Singh, V.P., Kaur, H., and Singh, P. 2012. Cost-benefit analysis of cow milk production in Punjab. Journal of Agricultural Development and Policy. 22(1):67-74.

Narke, A. 2017. 45 ${ }^{\text {th }}$ DIC: a grand success. Indian Dairyman 69(2):16-17.

Sharma, H.O., and Raghuwanshi, N.K. 2010. 'Economics of Production, Processing and Marketing of Fodder Crops in Madhya Pradesh' Agro Economic Research Centre Study No. 99, JNKVV, Jabalpur, Madhya Pradesh.

Singh, H., Singh, V.P., and Kaur, I. (2018) Availability of green fodder in various zones of Punjab state. Indian J Econ and Develop 14(1a): 383-87.

\section{How to cite this article:}

Harparteet Singh, Varinder Pal Singh and Inderpreet Kaur. 2018. Cost Analysis of Processing of Green Fodder Crops in Punjab State. Int.J.Curr.Microbiol.App.Sci. 7(11): 832-837. doi: https://doi.org/10.20546/ijcmas.2018.711.098 